\title{
Workplace Stretching Exercise toward Reduction Job Burnout among Workers Pt. X International, Indonesia
}

\author{
Atjo Wahyu ${ }^{1 *}$, Stang Stang ${ }^{2}$, Syamsiar Russeng ${ }^{1}$, Andi Ummu Salmah ${ }^{3}$, Nur Alam Dahlan ${ }^{1}$, Anwar Mallongi ${ }^{4}$, Muhammad Restu \\ ${ }^{1}$ Department of Occupational Health and Safety, Public Health of Faculty, Hasanuddin University, Makassar, Indonesia; \\ ${ }^{2}$ Department of Biostatistics, Public Health of Faculty, Hasanuddin University, Makassar, Indonesia; ${ }^{3}$ Department of Family \\ Planning Health, Public Health of Faculty, Hasanuddin University, Makassar, Indonesia; ${ }^{4}$ Department of Environmental Health, \\ Public Health of Faculty, Hasanuddin University, Makassar, Indonesia; ${ }^{5}$ Biotechnology and Tree Breeding Laboratory, Faculty \\ of Forestry, Hasanuddin University, Makassar, Indonesia
}

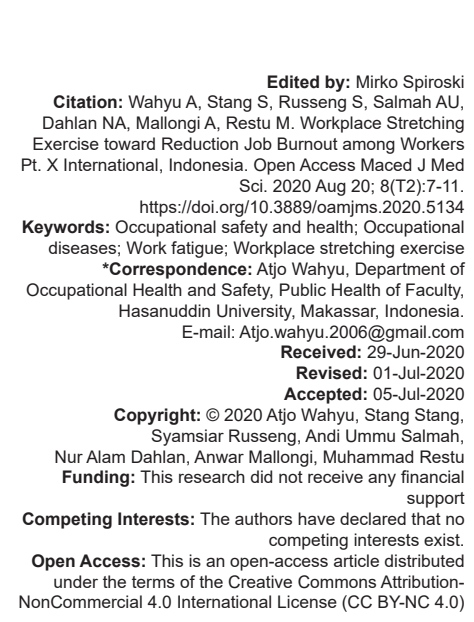

Abstract

BACKGROUND: Occupational safety and health are health sciences that are applied through work and the work environment to obtain the highest degree of health both physically, mentally, and socially through preventive and curative efforts in the workplace. The emergence of work fatigue in workers is evidence of a decrease in bodily functions caused by both individual factors and the work environment so that precautions are needed.

AIM: This study aimed to see the effect of workplace stretching exercise on work fatigue in workers at PT. X International, Indonesia.

METHODS: This study used a quasi-experimental study with one group pre-test and post-test design. Respondents were 30 people selected by purposive sampling and met the study inclusion criteria. The provision of workplace stretching exercises was carried out for 15 working days and is given every 10 am after workers work for $2 \mathrm{~h}$.

RESULTS: The mean of work fatigue before intervention (pre-test) is 454.8133 and the average work fatigue after an intervention (post-test) is 321.9133 so that there are differences in the average work fatigue before and after the intervention.

CONCLUSION: Workplace stretching exercise intervention affects reducing work fatigue in production workers of PT. X International Indonesia.

\section{Introduction}

An occupational illness is a disease that arises due to occupational factors (environment and work tools). According to the World Health Organization, about 50\% of the global population are workers, with reports from the International Labor Organization (ILO) that there are at least 2.34 million cases of deaths caused by accidents or work-related diseases [1]. Meanwhile, 160 million workers suffer from occupational diseases with non-fatal work. Losses due to occupational illnesses and deaths due to occupational factors account for $4 \%-6 \%$ of the gross domestic product in related countries and regions in the world [2].

Work fatigue is one of the risk factors for the decrease in the health status of workers, which can also be measured by increasing the pulse rate [3], whereas workers who experience integrated health improvement are proven to increase work productivity [4]. The development of muscle fatigue is usually quantified as a decrease in muscle power capacity [5]. Fatigue felt by workers varies, among others, feeling sleepy, dizzy, bored, palpitations, and lazy to move. Things that cause work fatigue could come from work environment factors (work intensity, work climate, lighting, noise, etc.) and individual factors [6].

Based on the survey results, residents of developed countries are identified as having work fatigue of around $10-50 \%$. Then, data released by the ILO in 2010 showed that around 2 million workers die every year because work accidents are preceded by work fatigue. A study conducted in New Zealand from 2002 to 2004 reported that there were at least 134 work accident cases where $11 \%$ were caused by risk factors for work fatigue [7].

PT. X International, Indonesia, is one of the largest wood processing companies in Makassar city, whose main products are furniture for storing the ashes for Japanese people called Butsudan. This company has four factories which are still operating today. At factory 1 , cutting or woodcutting process, factory 2 sanding wood, factory 3 painting, and factory 4 assembly and packing, there were also wood drying machines, 
boilers, several wood warehouses, and 2 offices. The long production process requires that the company has a stretching program or workplace stretching exercise to give the company a break and stretch the muscles of the workers.

The selection of factory 2 as a place of research is because homogeneous forms of work carried out by workers are sanding cut wood. Besides, the number of factory 2 workers is the highest compared to other factories. The length of the wood processing process to become butsudan and the target of the sandpaper that must be achieved requires them to do work from 8 to 12 noon without any break for workplace stretching exercise. Based on the results of previous studies it was published that the percentage of work fatigue of $58.5 \%$ experienced by workers at PT. X International Indonesia [8]. Based on this study, this study aims to see whether workplace stretching exercises can reduce work fatigue in factory workers 2 PT. X International Indonesia.

\section{Materials and Methods}

This research was conducted at PT. $X$ International Indonesia, Makassar City, South Sulawesi. The type of research was a quasi-experiment with one group pre-test and post-test design.

The population in this study was factory workers 2 PT. X International Indonesia, sample 30 respondents who were selected by purposive sampling and met the inclusion criteria, namely, men, working period of at least 1 year, experiencing work exhaustion, and willing to follow the research by signing informed consent.

Data collection was carried out by researchers using questionnaires, digital reaction timers, analog scales, and stature meters. Measurement of work fatigue is done twice, namely, before giving workplace stretching exercise intervention and after giving workplace stretching exercise. The provision of workplace stretching exercises is given for 15 days and every $10 \mathrm{am}$.

Data on individual factors in this study include (age, years of service, body mass index, smoking status, and exercise habits) and work fatigue before and after workplace stretching exercise intervention using SPSS for windows 23. The average difference in work fatigue before and after the intervention is used analysis paired sample t-test.

\section{Results}

Table 1 showed that the average age of research respondents at factory $2 \mathrm{PT}$. X International
Indonesia, 38.67 years and the average respondent have work period 14 years. The mean body mass index of the respondent is 25.1. Meanwhile, the category of smoking habits of respondents $90 \%$ had smoked the past year and $10 \%$ had never smoked the past year. Then, the exercise habits category showed that $26.7 \%$ had exercise habits and $73.3 \%$ had exercise habits. Category of body mass index showed that as much as $56.7 \%$ of workers have normal BMI, $30 \%$ overweight, and $13.3 \%$ obesity category.

Table 1: Characteristic respondents

\begin{tabular}{llll}
\hline Characteristic & $\%$ & Mean & Standard deviation \\
\hline Age & 100 & 38.7 & 7.7 \\
Working periods & 100 & 14.07 & 6.2 \\
Sports habits & & & \\
$\quad$ Ordinary & 26.7 & & \\
$\quad$ Unusual & 73.3 & & \\
Smoking status & & \\
$\quad$ Smoke & 90.0 & & \\
$\quad$ Do not smoke & 10.0 & & 2.8 \\
BMl & & \\
$\quad$ Normal & 56.7 & 25.1 & \\
$\quad$ Overweight & 30.0 & & \\
$\quad$ Obesity & 13.3 & & \\
\hline BMI: Body mass index & & & \\
& &
\end{tabular}

Table 2 showed that category of work fatigue before giving workplace stretching exercise intervention was the most in the moderate category by $46.7 \%$, mild category $33.3 \%$, and the severe by $20 \%$. Then, after being given intervention workplace stretching exercises mild category $93 \%$ and moderate category $6.7 \%$.

Table 2: Distribution by category of work fatigue in workers

\begin{tabular}{lllll}
\hline Category of work fatigue & \multicolumn{4}{l}{ Measurement of work fatigue } \\
\cline { 2 - 5 } & Pre-test & Post-test & \\
\cline { 2 - 5 } & $\mathrm{n}$ & 0 & 0 & 0 \\
\hline Normal & 0 & 33.3 & 28 & 93.3 \\
Mild & 10 & 46.7 & 2 & 6.7 \\
Moderate & 14 & 20.0 & 0 & 0 \\
Severe & 6 & &
\end{tabular}

Table 3 showed that there was a change in the average work fatigue before and after the workplace, stretching exercise intervention. The average work fatigue before the intervention was 454.8 and after work intervention was 321.9. Then, the results of paired sample T-test analysis resulted in sig. $0.001<0.05$ which means that there were differences in the average work fatigue before and after the workplace stretching exercise intervention in factory workers PT. X Internasional, Indonesia.

Table 3: Paired sample t-test analysis

\begin{tabular}{lllll}
\hline Work fatigue & Mean & Mean & Standard deviation & Sig. \\
\hline Pre-test & 454.8 & 132.9 & 68.2 & 0.001 \\
Post-test & 321.9 & & & \\
\hline
\end{tabular}

\section{Discussion}

Studies show that at least $46.7 \%$ of workers experience fatigue in the moderate category and $20.0 \%$ for fatigue in the severe category, after giving interventions perceived level of fatigue is dominant in the mild category or $93.3 \%$. This change is supported by results of the significance test that 
there are differences in the average work fatigue before and after the workplace, stretching exercise intervention in factory workers PT. X Internasional, Indonesia.

Fatigue and drowsiness in the workplace are consequences of modern industrial society, which can cause many accidents and poor mental and physical health outcomes, mostly due to work in high demand, long service periods, and circadian rhythm disturbances, to accumulative sleep debt common in many industries [9], [10]. According to Krausman et al. [11], fatigue can also be caused by intense cognitive activity on physical demands.

The effect of muscle fatigue is most likely explained by the composition of the type of muscle fibers, where absolute strength is higher when young and generally higher for men [12]. Age is one of the individual factors that can cause work fatigue in workers, which is associated with changes in physiology in a person's body and affects physical endurance and capacity as well as productivity [13]. This is in line with research conducted by Budiman et al. [14] that increasing the age of a worker will also increase the level of fatigue due to a decrease in mental and social functional capacity before the age of 45 years. An interesting thing resulted from research conducted by Amin et al. [15] that the peak of human physical capacity is when they enter the age of 25 years. And will experience a decrease in muscle strength, sensory ability, decreased visual acuity, speed to distinguish things, and the ability to remember long-term at the age of 50-60 years.

The influence of work tenure on work fatigue so far has not been proven clearly because there are still studies that explain that work tenure is not related to work fatigue. The same thing is explained in the research of Salasa et al. [16] that there is no relationship between work period with work fatigue in Loining workers at PT. X Foods International, where the longer the work period, the more skilled a worker will be the average tenure at factory 2 PT. $X$ International is 14 years or it could be said that workers have a long work period and have directed habits.

Good nutrition in the workforce will increase the degree of worker's health, efficiency, work productivity, maintain endurance, balance the nutritional, and calorie needs of the work done. Body mass index is one of the factors causing work fatigue in workers because, with good nutritional status, a worker will have a better work capacity and endurance compared to workers who have less nutritional status [17]. This is supported by the study of Langgar et al. [18] that there is a relationship between the nutritional statuses of workers with work fatigue experienced by workers from the company Tahu Baxo Bu Pudji on the Ungaran. Besides, nutrition for workers can also maintain the body, repair tissue cells so that a person can do his job well. Research conducted by Diana et al. [19] showed that workers with underweight nutritional status have poor capacity and endurance compared to workers with normal nutritional status. Thus, these workers need food as a source of energy, protein, vitamins, and minerals. The substance is then burned in the body and then used as a source of energy for work.

Workplace stretching exercise is a workout stretching exercise adopted from the Toronto University and its movements are designed according to the principle of stretching the muscles which aim to extend the muscles, so they become relaxed and supple. Some of the benefits of stretching in the workplace are improving circulation, improving work posture, improving coordination, relieving stress, increasing flexibility, wiggle room [20], and preventing injury [21].

Work fatigue is a common problem that often experienced by the working population and usually appears after work and is acute or chronic. Work fatigue occurs due to a decrease in physical and cognitive functioning of the body [22]. In addition, work fatigue can also be caused by factors outside the work environment such as activities at home before going to the office/workplace, lifestyle, and nutrition/food intake at home. The effects of fatigue on workers can be in the form of disability and absenteeism [23]. More clearly stated by Prof. Meijman that work fatigue is an effect of physiological adaptation that can save the body from the risk of excessive energy released by the body, in contrast to physiological fatigue which is feedback from the body that causes reduced drive and motivation and causes mental and physical [24].

Paired sample t-test results showed that there were differences in the average work fatigue before and after the administration of workplace stretching exercise intervention. This happens because this intervention provides an opportunity for muscle relaxation or rest to prevent muscle tension. Besides, if the workplace stretching exercise is used as a routine, it will also affect the complaints of musculoskeletal disorders. This is consistent with research conducted by Hastuti [25] which states that there is a decrease in work fatigue after giving stretches to workers. Various relevant studies prove the positive influence of stretching on decreasing the level of fatigue [26], [27], [28]. Theory of conservation of resources states that every individual will try to get and maintain the things they value to avoid work stress. Besides, another way to deal with work fatigue is to do relaxation and physiological release at work [29], [30], [31], [32].

\section{Conclusion}

Workplace stretching exercise intervention affects reducing work fatigue in production workers of PT. X International Indonesia. 


\section{Recommendation}

It is expected that top management can make policies related to the provision of workplace stretching exercise interventions to workers in the industry so that the level of fatigue in workers can be minimized, which has a positive impact on results and increased productivity.

\section{References}

1. Xia T, lles R, Newnam S, Lubman DI, Collie A. Work-related injury and disease in Australian road transport workers: A retrospective population based cohort study. J Transp Health. 2019;12:34-41. https://doi.org/10.1016/j.jth.2018.11.002

2. Lu Y, Yan H, Zhang L, Liu J. A comparative study on the prediction of occupational diseases in china with hybrid algorithm combing models. Comput Math Methods Med. 2019;2019:8159506.

3. Thamrin $Y$, Wahyu $A$, Muis $M$, Russeng SS, Birawida $A B$, Amqam $\mathrm{H}$, et al. Determinants of occupational health and safety problems among seaweed workers in takalar regency. Indian J Public Health Res Dev. 2019;10(1):1214-9. https://doi. org/10.5958/0976-5506.2019.00221.3

4. Special Committee on Health, Productivity, and Disability Management. Healthy workforce/healthy economy: The role of health, productivity, and disability management in addressing the nation's health care crisis: Why an emphasis on the health of the workforce is vital to the health of the economy. J Occup Environ Med. 2009;51(1):114-9. https://doi.org/10.1097/ jom.0b013e318195dad2

PMid:19136880

5. Enoka RM, Duchateau J. Muscle fatigue: What, why and how it influences muscle function. J Physiol. 2008;586(1):11-23. https://doi.org/10.1113/jphysiol.2007.139477

PMid:17702815

6. Da Costa BR, Vieira ER. Stretching to reduce work-related musculoskeletal disorders: A systematic review. J Rehabil Med. 2008;40(5):321-8. https://doi.org/10.2340/16501977-0204 PMid: 18461255

7. Dewita T. Pengaruh stretching terhadap penurunan kadar asam laktat pada pekerja bagian produksi PT. X. J Ind Kreatif. 2018;2(2):125-30. https://doi.org/10.36352/jik.v2i2.124

8. Rachman H. Gambaran Kelelahan Kerja Pada Pekerja DI PT Maruki Internasional Indonesia Makassar, Doctoral Dissertation, Universitas Islam Negeri Alauddin Makassar; 2013. https://doi. org/10.24252/minds.v4i1.3140

9. Caldwell JA, Caldwell JL, Thompson LA, Lieberman HR. Fatigue and its management in the workplace. Neurosci Biobehav Rev. 2019;96:272-89. https://doi.org/10.1016/j. neubiorev.2018.10.024

PMid:30391406

10. Sadeghniiat-Haghighi K, Yazdi Z. Fatigue management in the workplace. Ind Psychiatry J. 2015;24(1):12-7. https://doi. org/10.4103/0972-6748.160915

PMid:26257477

11. Krausman AS, lii HP, Wilson RM. The Effects of Physical Exertion On Cognitive Performance (No. Arl-Tr-2844). Adelphi: Army Research Lab Aberdeen; 2002.

12. Collins JD, O'Sullivan L. Age and sex related differences in shoulder abduction fatigue. BMC Musculoskelet Disord. 2018;19:280. https://doi.org/10.1186/s12891-018-2191-7 PMid:30081890

13. Susihono W, Adiatmika IP. Implementation of Total Ergonomics Approach through Multidisciplinary Sciences for the Improvement of Workers' Health Quality: Literature Review Doctoral Dissertation Udayana Bali-Indonesia; 2009.

14. Budiman $A$, Husaini $H$, Arifin $S$. Hubungan antara umur dan indeks beban kerja dengan kelelahan pada pekerja di PT. Karias tabing kencana. J Berkala Kesehatan. 2017;1(2):121-9. https://doi.org/10.20527/jbk.v1i2.3151

15. Amin MD, Kawatu PA, Amisi MD. Hubungan antara umur dan status gizi dengan kelelahan kerja pada pekerja lapangan PT pelabuhan Indonesia IV (persero) cabang bitung. eBiomedik. 2019;7(2):1-5. https://doi.org/10.31289/diversita.v5i1.2471.s150

16. Salasa N, Kolibu FK, Punuh MI. Hubungan antara umur, masa kerja dan status gizi dengan kelelahan kerja pada pekerja di bagian loining PT. Sinar pure foods internasional bitung. Med Kesehatan. 2017;9(3):1-9. https://doi.org/10.29241/jmk.v3i1.87

17. Suwondo MP, Adi DP, Lestyanto MS. Hubungan antara iklim kerja, asupan gizi sebelum bekerja, dan beban kerja terhadap tingkat kelelahan pada pekerja shift pagi bagian packing PT. X, kabupaten kendal. J Kesehatan Masyarakat Univ Diponegoro. 2013;2(2):1-11. https://doi.org/10.30644/rik.v8i1.224

18. Langgar DP, Setyawati VA. Hubungan antara asupan gizi dan status gizi dengan kelelahan kerja pada karyawan perusahaan tahu baxo bu pudji di ungaran tahun 2014. VISIKES. 2014;13(2):127-35. https://doi.org/10.33757/jik.v2i2.127

19. Diana E, Evendi A, Ismail I. Hubungan status gizi dengan kelelahan kerja pada karyawan stasiun pengisian bulk elpiji di indramayu. Afiasi. 2019;2(3):84-8. https://doi.org/10.31943/ afiasi.v3i1.12

20. Chen $\mathrm{HM}$, Wang $\mathrm{HH}$, Chen $\mathrm{CH}$, Hu HM. Effectiveness of a stretching exercise program on low back pain and exercise selfefficacy among nurses in Taiwan: A randomized clinical trial. Pain Manag Nurs. 2014;15(1):283-91. https://doi.org/10.1016/j. pmn.2012.10.003

PMid:23266331

21. Park HK, Jung MK, Park E, Lee CY, Jee YS, Eun D, et al. The effect of warm-ups with stretching on the isokinetic moments of collegiate men. J Exerc Rehabil. 2018;14(1):78-82. https://doi. org/10.12965/jer.1835210.605 PMid:29511656

22. Abd-Elfattah HM, Abdelazeim FH, Elshennawy S. Physical and cognitive consequences of fatigue: A review. J Adv Res. 2015;6(3):351-8. https://doi.org/10.1016/j.jare.2015.01.011 PMid:26257932

23. Aryal A, Ghahramani A, Becerik-Gerber B. Monitoring fatigue in construction workers using physiological measurements. Autom Constr. 2017;82:154-65. https://doi.org/10.1016/j. autcon.2017.03.003

24. Van Dijk FJ, Swaen GM. Fatigue at work. Occup Environ Med. 2003;60:i1-2.

PMid: 12782739

25. Hastuti LS. The Effect of Workplace Stretching-Exercise (WSE) To Musculoskeletal Discomfort and Work Fatigue of Sewing Workers in CV. X Sukoharjo Central Java. Dubai: ITP PRESS; 2016. https://doi.org/10.21063/ictis.2016.1094

26. Kim JS, Lee S, Kim MS. Effects of stretching on fatigue and concentration in high school students. J Korean Acad Child Health Nurs. 2006;12:196-203.

27. Kim HY, Yeun YR, Kim SJ. Preventive effects of stretching and stabilization exercises on muscle fatigue in mobile phone users. J Phys Ther Sci. 2016;28(9):2529-32. https://doi.org/10.1589/ jpts.28.2529 


\section{PMid:27799686}

28. Sundstrup E, Jakobsen MD, Brandt M, Jay K, Aagaard P, Andersen LL. Strength training improves fatigue resistance and self-rated health in workers with chronic pain: A randomized controlled trial. Biomed Res Int. 2016;2016:4137918. https://doi. org/10.1155/2016/4137918

PMid:27830144

29. Mallongi A, Natsir MF, Astuti RD, Rauf AU, Rachmat M, Muhithd A, et al. Potential ecological risks of mercury contamination along communities area in tonasa cement industry Pangkep, Indonesia. Enferm Clín. 2020;30(4):119-22. https://doi.org/10.1016/j.enfcli.2019.10.054

PMid:32545027

30. Mallongi A, Limbong E, Naiem F, Ishak H, Basri S, Saleh M, et al. Health risk analysis of exposure to mercury $(\mathrm{Hg})$ and cyanide $(\mathrm{CN})$ in Kayeli village communities Teluk Kayeli district Buru regency. Enferm Clín. 2020;30(4):427-30. https://doi. org/10.1016/j.enfcli.2020.03.007

PMid:32545105

31. Garrick A, Mak AS, Cathcart S, Winwood PC, Bakker AB, Lushington K. Non-work time activities predicting teachers' workrelated fatigue and engagement: An effort-recovery approach. Aust Psychol. 2018;53(3):243-52. https://doi.org/10.1111/ ap.12290

32. Russeng SS, Saleh LM, Virani D, Latief AW, Mallongi A The investigation of the lactic acid change among employee of national electrical power plan. Indian $\mathrm{J}$ Public Health Res Dev. 2018;9(1):361-5. https://doi. org/10.5958/0976-5506.2018.00067.0 